$\mathrm{B}$ ：幅、D：深さ、 $\theta_{\varphi}$ : 角度

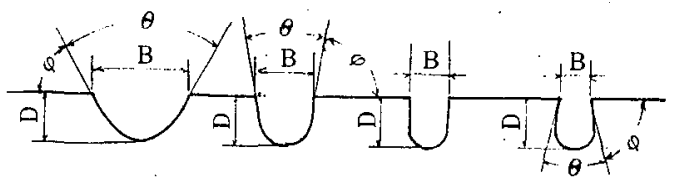

(a)

(b)

(c)

(d)

図 5.3 ガウジング浑の断面形状

長するおそれあある，特に，予熱及びパス問温度下限が 指定されているときには問題がある。

\section{2 裹はつり (ガゥジング) 検査}

表溶接（仮付溶接部を含む）の尔陷を除去する褧はつ りの検查は，站はつりの目的を考えれば重要はことが理 解できる、アークエアガウジング又はガスガウジングを 行うときは, ガウシンング作業自体が検查の役割を持って いる. それは，ガウジングの進行に従って，表溶接の久 宿が掘り出され，目に見えるからである，ガウジングを だ性的に行うと，ての蛽重な情報を捨てるととになる。

ガウジング後の検査は，これが集溶接の品質を左右す るととのほか, 溶接中の検查で唯一と言ってよい継手内 部の検查なので極めて重要である。この検査は主として 目視によって行われるが，漛の形状についてはゲー㜔類 を, 溝面の欠陷の検出には浸透又は磁粉探嘚試験を適用 することあある。

潬の形状では, 蝠・深さ及びその比, 表面との角度及 び断面形状の連綕性がチェックされる，图 5.2 亿その要 点を示す．ガウジングは，准が発見されたときにはと れを除去するように行うので, 樑さ（及び幅）は，部分 的炕大きくなるとがある。
满の表面では，欠陷の徴候，表面の四凸，スラグや炭 菜の付着はどを調べる。洅断面が図 5.3 (d) のように きんちゃく形になっているときには，炭素が付着してい ることが多いが，乙の場合は形状検查で指摘し，グライ ンダ等により整形すべきである．欠陌が残っているとき は，更にガウジング又は研削等により除去し，再検査す る必要がある.

\section{3 収縮及び変形など}

收縮や変形，場合によっては目違いなどは，溶接終了 後に検査されるが，ての段階で不合格になる之修正が困 難になるので，溶接中に必要な計測等によってチェック し，完成後にトラブルが生じないようにし，また，必要 があれば早く修正・処貢することが望ましい。

突合廿継手や $\mathrm{T}$ 継手の角変形は特注意が必要で，㭘 查結果によっては拘束方法やジグの配慮，溶接順序の変 更，中間パスのピーニングなどの処置が取られることも ある.繸曲がり変形や座屆形式の变形もチェックされる.

これらの検查, チェックには，構造物や継手北式に応 じて，スケールや各種の一般用又隹用のゲーシ，計測 用ジグなどが用いられる。

\section{4 その他の溶接中の検查}

（1）中閒パスでは，前パスの情況のチェック・確認及 び各パス終了時にスラグ・スケールを除去しての目視に よる確認が，主として自主検查として行われる。

(2) 予熱・パス間温度などは, 溶接電流・電圧・速度 等ととすに溶接施工管理の一環として行われるが, 温度 チョーク等によるチェックを別途行うととがある. 加 熱を自動制御するときには，そのチェックが管理上必要 となる。

\title{
6. 耐圧試験・漏れ試験など*
}

成田圈郎**

\author{
Pressure Test*
}

by Kunio Narita**

\section{6. 耐圧試験・漏れ試験など}

圧力容器・配管・パイプライン等の受任設借では，耐
压試䍄及び屚れ試験は，設䚛の完成検査の中で重要な地 位を占めている，眝啃類では，液の重量による圧力がか かるので, 水張試験が行われる.

構造物や機峨では，クレーンのように過負荷の载荷陚 




(1) 使用条件(気体)

(2) 使用条件 $\times 1.5$

(3) 頂部で(2)を淽 足, 充水

(4) 頂部で (2)を巣 足, $1 / 2$ 充水 (気腹併用)

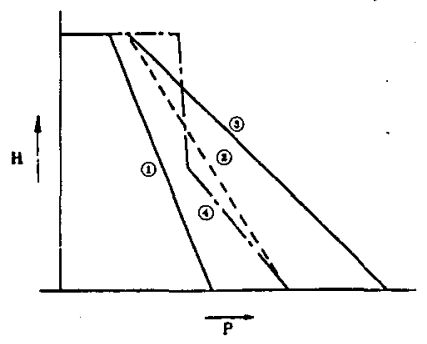

(1) 使用条件（液化 ガス)

(2) 使用条件 $\times 1.5$

(3) 頂部で(2)を満 足, 充水

(4) $1 / 2$ 充水, 気液 併用

図 6.1 気液併用試験の圧力 ${ }^{1)}$

験を行うものなど，各種の過負荷試験が行われるが，荷 重の性格が多汥にわたるので，耐王試験を過真荷試験の 一形式として取り上げ，説明するる。

\section{1 耐圧試験}

耐圧試験は，設計生力の1.25〜1.5倍の圧力を水を用 いて挂けるのが普通である．倍率は超高王の場合は低娍 され，常压に近い場合には增大される，安全な流体であ る水を用いるが，設備は完成後初めて，しか6使用中に 受けることのない高い玨力を受けるので, 設計・工作が 悪ければ設備に損傷又は変形を生ずるととがある。

耐压試験の目的は，設備の酎圧性能・棈造強度を確認 し，併せて著しい漏れがないてとをチェックすることで ある.したがって，微少漏れの検出は含まれず，漏れ試 験の対象とされる，水を用いて耐圧試験を行うことが不 適当なときは，水以外の液体，空気又枯不活性ガス（酸 素及び内容物之反応しないガス）を用いるが，乙の場合 には保安上の注意が特別に要求され，また，試験圧力も 水を用いる場合より低くするのが普通である。

(1) 而庄試験条件

耐死試験の際に設临が受ける荷重は, 压力と加圧流体 の重量である，気体，気体と液体の混合物又は軽い液体 を入れる設備を水で満たし，加任すると，下部には水の 重量による大きな荷重が加わる．特に，頂部設計圧力が 低い場合には，圧力による応力に比べて重量による応力 の割合が大きく，重量が支えられなくなる，また，本体 が重量に酎えても，支柱・支持構造又は基礎が耐えられ ないことがある。大型球形ガスタンクで気体による耐圧 試験を行い，LNG 平底円筒形眝槽で設計液面まで水を 張らない場合があるのはとのような理由による。他方，
LPG や酸絜の球形タンクは，水を用いて耐死試験を行 うよう設計されている (図6.1参照).

基本的には，要王部分のいかなる点に拈いても

$$
\begin{aligned}
& P_{T} \geq \alpha \cdot P_{D} \\
& \sigma_{T} \geqq \alpha \cdot \sigma_{D}
\end{aligned}
$$

ここで $P_{T}$ : 試験時のE力, $P_{D}$ : 設計压力 $\sigma_{T}:$ 試験時の応力, $\sigma_{D}:$ 設計応力 $\alpha:$ 耐圧試験圧力と設計压力との比

となることが望ましいが，このようにすると $\sigma_{T}$ が降伏

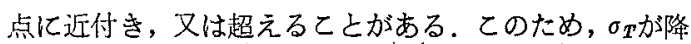
伏点（又は酎力）規格値の90\%を超えないようにするな どの歯止めがかけられるが，そうすると，場所によって は $\sigma_{T} / \sigma_{D}$ の值が小さくなる。乙の分は，施工・施工管 理及び非破壤試験等によって補うが，後に述べる過負荷 の効果が小さくなることは免れない.

同じことは，硫酸やかせいソーダ水溶液のように重い 液体を入れる眝槽の水張試験にもいえる，乙の場合，眝 槽いっぱいに水を張っても，底部の圧力は使用時の圧力 に達しない。

\section{(2) 加圧の方法}

水を用いる場合には，水を渾なし，些気を排除して压 力を加える. 圧力が高くなってからは，安全に注意しな がら稌ヶに舁王し，所定の王力まで高め，保持する。温 度変化等の影響で圧力が変動するときは，压力が安定し てから所定の時間（通常 5 〜30分）保持し, 異常のない ことを確認する．変形の計測を行うとともあるが，計测 装置をあらかじめセットし，遠隔測定を行うべきであ Ђ.

気体を用いる場合には，特に高王側で段階的に加圧を 行い，加压を停止しては安全を確認するという手覑を繰

\begin{tabular}{|c|c|}
\hline 点 & 点 \\
\hline  & 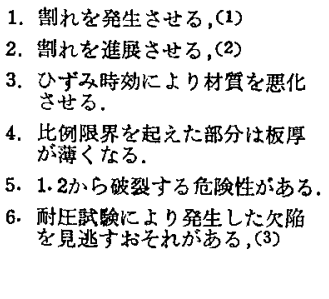 \\
\hline
\end{tabular}

表 6.1 耐圧試験の利害1)

注 (1) 溶接作業直後に耐王武臨を行ったり，後熱処理が不十分であっ

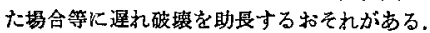

（8）溶接後熱処理（伈力除去镜鈍）をしていないるのはこの倾向 が強い.

(3)この提案では，この欠点をなくすよう検查を課してある.現在



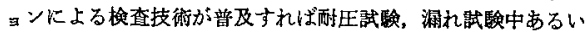
は使用中に剖れを検出することができるので，保安の向上が期 待される。 
り返す，温度の変化にむ十分注意する，気波併用の場合 は，水をある程度満たし，残りの空間に気圧を加えるの で，気体を用いる場合之同様に取り扱う。

\section{2 酎圧試験の効果}

酎圧試験は, 生力容器・配管等の受圧棈造の圧力に酎 える性能を確認するものであるが，通常受ける压力（常 用㽵力，設計圧力）上りも高い压力で試験されるので，

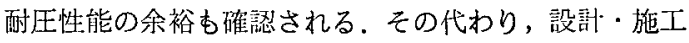
が不適当なときは，耐圧試験の際に破壊や著しい漏れを 生ずるととがありり，人命に関する事故む古来多く起こっ ている.

耐压試験の利点及び久点をまとめて表 7.1 亿示す。特 K, 利点 3 の機械的応力除去の効果は，その後のぜい性 破壊の発生防止に役立与，気体を入れての運転や漏れ試 験の安全性を高めている。しかし，ての効果む，疲れや 腐食等に応力葻食割れ等が設借の使用中に進行するとと れに相殺されるので，然条件に頼りにしてはならない。

安全な流体である水を用いる耐圧試験（水圧試験） は，表6.1に示す効果によって広く用いられており，水圧 試験の適用できない受生設供では，材料選定・設計・施 工及び武験検查に特別の注意が必要である。利点 6 のよ うに,proof test として, 強度設䚵の困難な形状のものの 酎圧性能を確認することもできる。この場合にはひずみ ゲージや塗料による応力（ひずみ）の調查が行われる。

\section{3 漏九試験}

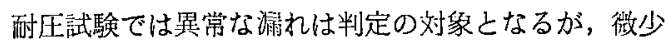
漏れは試験の対象ではない，そてで，耐圧試験に引き続 いて死力を常用圧力まで下げ，又は耐压試験の後に別個 に漏れ試験が行われる。耐压試験の後に，これより低い 試験圧力で行うため, 耐圧試験よりはるかに安全で, 漏 れを直接検查できる．波体の漏出，気体の漏出による発
泡や気体又はこれに混入したガス（フロン，ヘリウム， アンモニア等) の検知等によって漏れを調べる.

耐圧試験に先立って機械継手等の漏れを調べる予䚚漏 れ検知は，漏れ試験とは異なり，耐圧試験による構造安 全性の確認がされていないので，十分に低い压力（例え ば常用圧力の $10 \%$ 又は $0.35 \sim 1.8 \mathrm{kgf} / \mathrm{cm}^{2}$ 以下) で行う。 圧力を高くすると気圧試験と同様の危険が伴う。

埋設パイプラインのように，漏れの直接検知が困難な あのでは，試験圧力を例えば24時間以上保持して，圧力 （記録圧力計及び重量平衡式圧力検定器を用いる）及び 温度の計測により，漏れのないととを確認する。

\section{4 耐圧試験・気密試験実施上の注意}

耐圧・気密試験は受圧設借にとっては重要な試験なの で，設計の段階から十分慎重に計画し，また，具体的に 手順書を作って適切かつ安全に実施するととが何よりも 大切である。

湫圧試験前には，主要溶接部の非破壊試験などの試験 検査を済ませておかなければならない，遲れ割れによる 破買の防止には，溶接完了後非破壊検査まで及び耐圧試 験までの時間を十分に取るのがよい，補修溶接などでて の時間を短維するときには，材料及び溶接施工法に応じ て熱後等の荤れ割れ防止の措置を確実に行う必要があ る.

低温用貯槽や重い液体の眝槽などの耐圧試験, 水張試 験には，それぞれの規定があるが，6.1，6.2で述べたよ うに，なお検討を要する点も残されている。

\section{参 考 文 献}


験及び漏动試験に関寸る握案”（49年）

2）同上“同上，資料編”（同上)

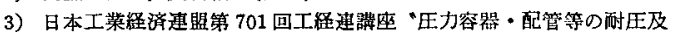



\section{7. 溶接後の処理と検査}

成田图 郎**

\section{Welding Inspection and Various Treatment after Welding*}

by Kunio Narita**

\section{7. 溶接後の処理と検査}

非破罗試験方法などを用いる溶接部の検査については III 以降で述べるが，溶接後，その評洒のための試験検查 が行われるまでには，溶接終了時の自主検査，溶接部の 